\title{
A Large Aggregation of Bowhead Whales (Balaena mysticetus) Feeding near Point Barrow, Alaska, in Late October 1992
}

\author{
S.W. LANDINO, ${ }^{1}$ S.D. TREACY,${ }^{1}$ S.A. ZERWICK ${ }^{1}$ and J.B. DUNLAP ${ }^{1,2}$
}

(Received 27 September 1993; accepted in revised form 23 March 1994)

\begin{abstract}
On 17 October 1992, during aerial surveys to monitor the bowhead whale migration across the Beaufort Sea, we encountered a large aggregation of feeding bowheads about $35 \mathrm{~km}$ NE of Barrow, Alaska. Nineteen sightings, for a total of 56 bowhead whales, were made over an area of open water and new ice. Most of the whales were engaged in bottom or near-bottom feeding. We returned to the area on 19 October and observed 16 groups and 11 singletons, for a total of 104 whales distributed over a $277 \mathrm{~km}^{2}$ area. The largest single group contained at least 30 whales. To our knowledge, our fall 1992 observations of feeding activity by a large aggregation of bowhead whales were made later in the calendar year than previously reported in the scientific literature and further demonstrate the periodic importance of areas near and east of Point Barrow as a bowhead feeding area in the fall.
\end{abstract}

Key words: bowhead whale, feeding, aggregation, fall migration, Beaufort Sea, Alaska

RÉSUMÉ. Le 17 octobre 1992, au cours de relevés aériens effectués en vue d'étudier la migration de la baleine boréale à travers la mer de Beaufort, on a rencontré une forte concentration de ces baleines en train de se nourrir, à environ 35 km au nord-est de Barrow, en Alaska. On a aperçu des baleines boréales 19 fois, pour un total de 56 individus, sur une superficie d'eau libre et de glace nouvelle. La plupart des cétacés étaient occupés à se nourrir sur le fond ou près du fond. On est retourné dans cette région le 19 octobre et on y a observé 16 groupes et 11 singletons, pour un total de 104 baleines, réparties sur $277 \mathrm{~km}^{2}$. La concentration la plus forte comprenait au moins 30 baleines. À notre connaissance, nos observations menées en automne 1992 sur une forte concentration de baleines boréales occupées à se nourrir ont été faites plus tard dans l'année civile que ne l'avait précédemment rapporté la documentation scientifique, ce qui prouve bien que les zones voisines et situées à l'est de Point Barrow ont à l'automne une importance périodique en tant qu'aire d'alimentation pour les baleines.

Mots clés: baleine boréale, se nourrir, concentration, migration automnale, mer de Beaufort, Alaska

Traduit pour la revue Arctic par Nésida Loyer.

Bowhead whales (Balaena mysticetus) commonly feed during the summer months in regions of the Canadian Beaufort Sea that have high standing stocks of zooplankton (Griffiths and Buchanan, 1982; Würsig et al., 1985, 1989; Richardson, 1987; Lowry, 1993). Bowheads also feed in the Alaskan Beaufort Sea during the fall migration (Braham et al., 1984; Ray et al., 1984; Lowry and Frost, 1984; Ljungblad et al., 1986; Richardson, 1987; Treacy, 1988; Moore and Clarke, 1992, 1993). Copepods are the principal prey for bowhead whales in the Canadian and eastern Alaskan Beaufort Sea, while euphausiids are the dominant bowhead prey in the western Beaufort Sea near Barrow, Alaska (Lowry and Frost, 1984; Lowry, 1993). Groups of feeding bowheads have previously been observed near Point Barrow in late September (Braham et al., 1984; Ray et al., 1984; Ljungblad et al., 1986) and in early October (Moore and Clarke, 1992, 1993; Moore and Reeves, 1993). We describe extensive feeding activity by a large aggregation of bowheads in nearshore waters northeast of Point Barrow in late October, at the very end of the fall migration across the Beaufort Sea.
From 31 August to 23 October 1992 scientists with the United States Minerals Management Service Bowhead Whale Aerial Survey Project monitored the bowhead whale migration across the Beaufort Sea. Surveys were flown in a de Havilland Twin Otter, based on random transect lines within predetermined survey blocks, with late-season effort in the western Beaufort Sea to document the end of the fall migration. Targeted survey altitude was $458 \mathrm{~m}$, with the lower limit at $305 \mathrm{~m}$ (see Treacy, 1993).

During a search of the westernmost survey block of the study area on 15 October, we observed 22 bowhead whales northeast of Point Barrow (Fig. 1a). It had been seven days since the last bowhead sighting, and the Beaufort Sea segment of the migration was presumed to have been nearly complete. Most of the whales sighted on 15 October were single animals involved in either traveling, resting, or diving. We returned to the same survey block on 16 October but did not detect bowheads, although sighting conditions were limited by high sea states, low clouds, and fog.

\footnotetext{
${ }^{1}$ United States Department of the Interior, Minerals Management Service, Alaska Outer Continental Shelf Region, 949 East 36 th Avenue, Room 603, Anchorage, Alaska 99508-4302, U.S.A.

${ }^{2}$ Present address: U.S. Department of the Interior, National Biological Survey, 1011 East Tudor Road, Anchorage, Alaska 99503, U.S.A. (C) The Arctic Institute of North America
} 


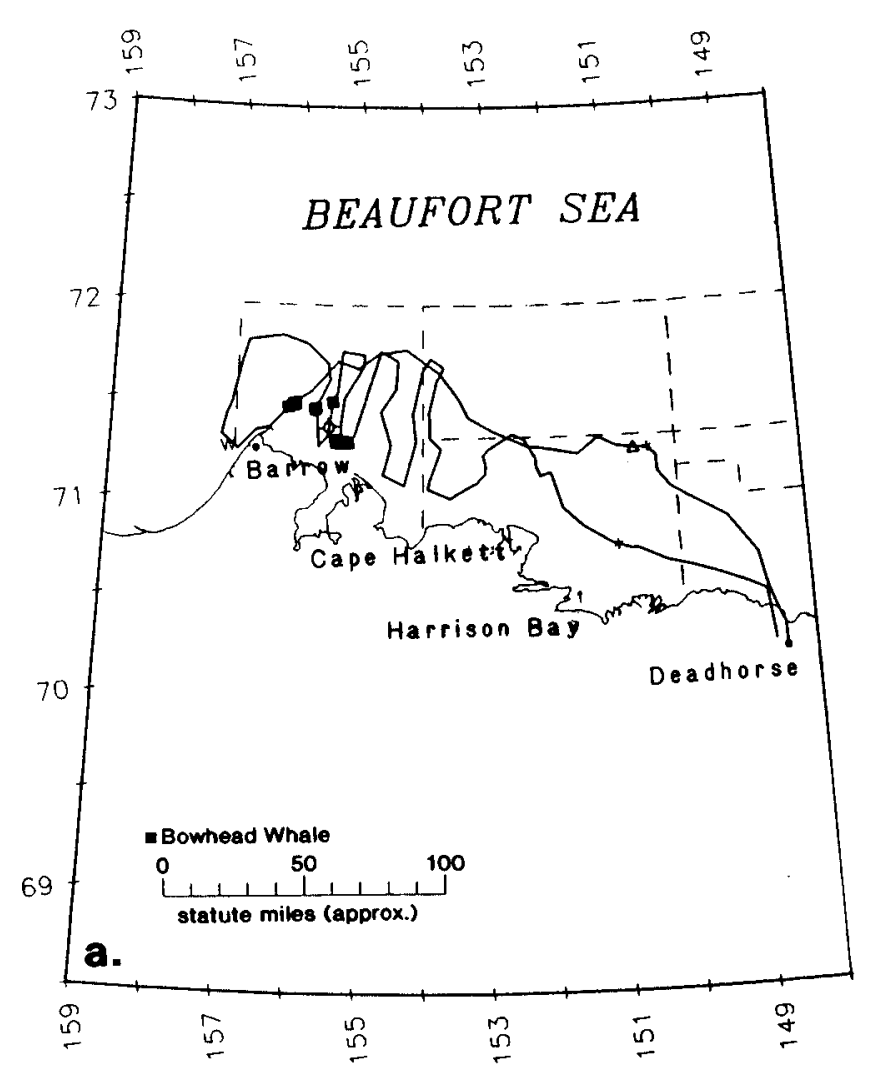

FIG. 1a. Survey track and location of bowhead whale sightings near and east of Point Barrow, Alaska for 15 October 1992.

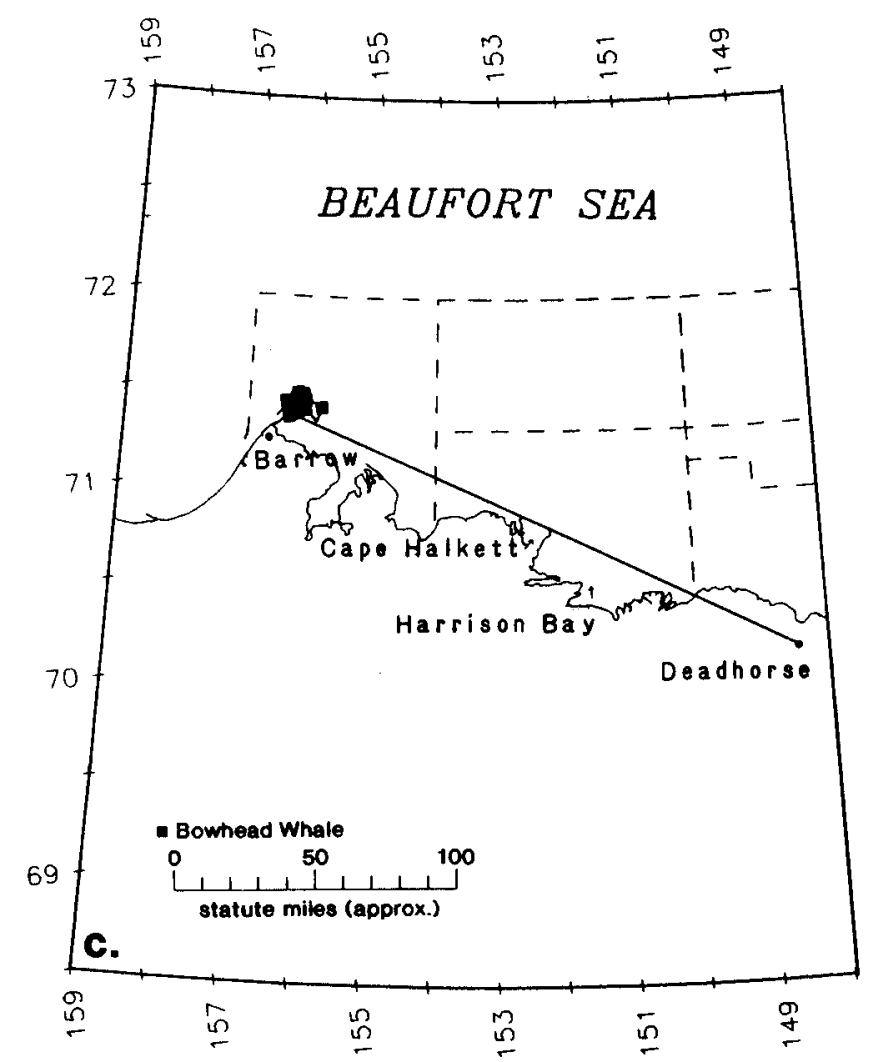

FIG. 1c. Survey track and location of bowhead whale sightings near and east of Point Barrow, Alaska for 19 October 1992.

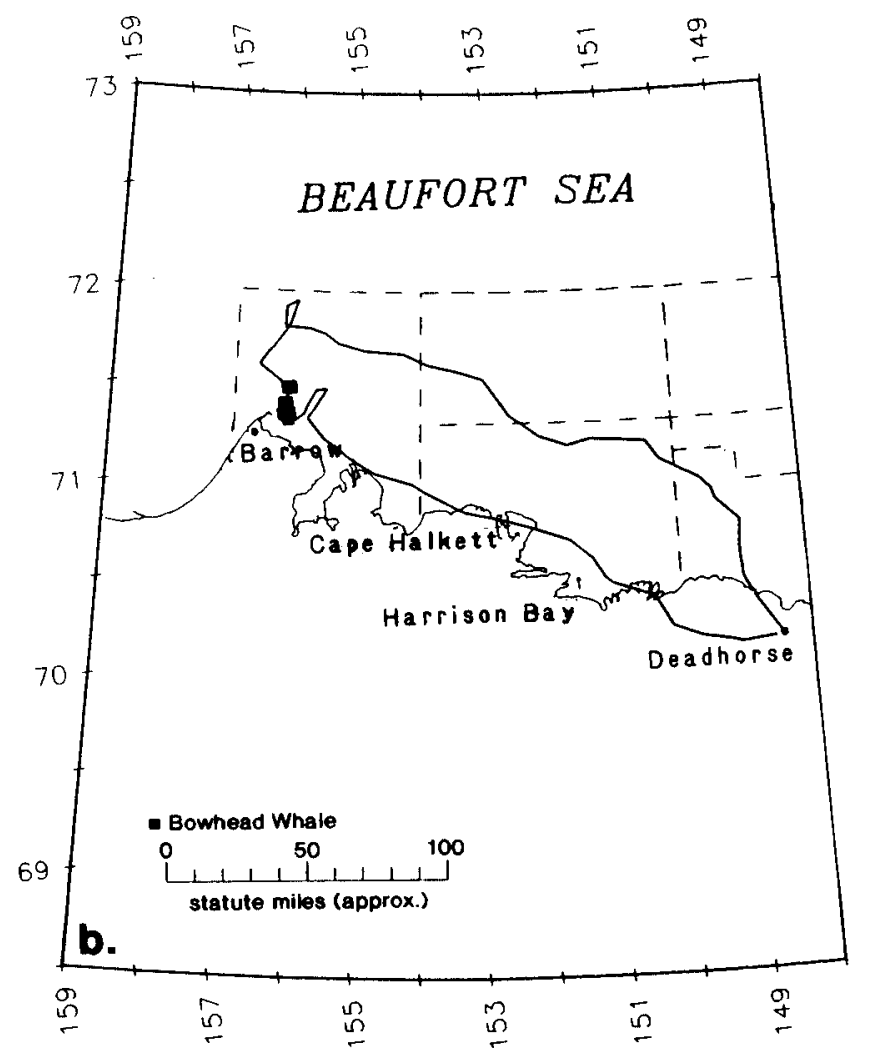

FIG. 1b. Survey track and location of bowhead whale sightings near and east of Point Barrow, Alaska for 17 October 1992.

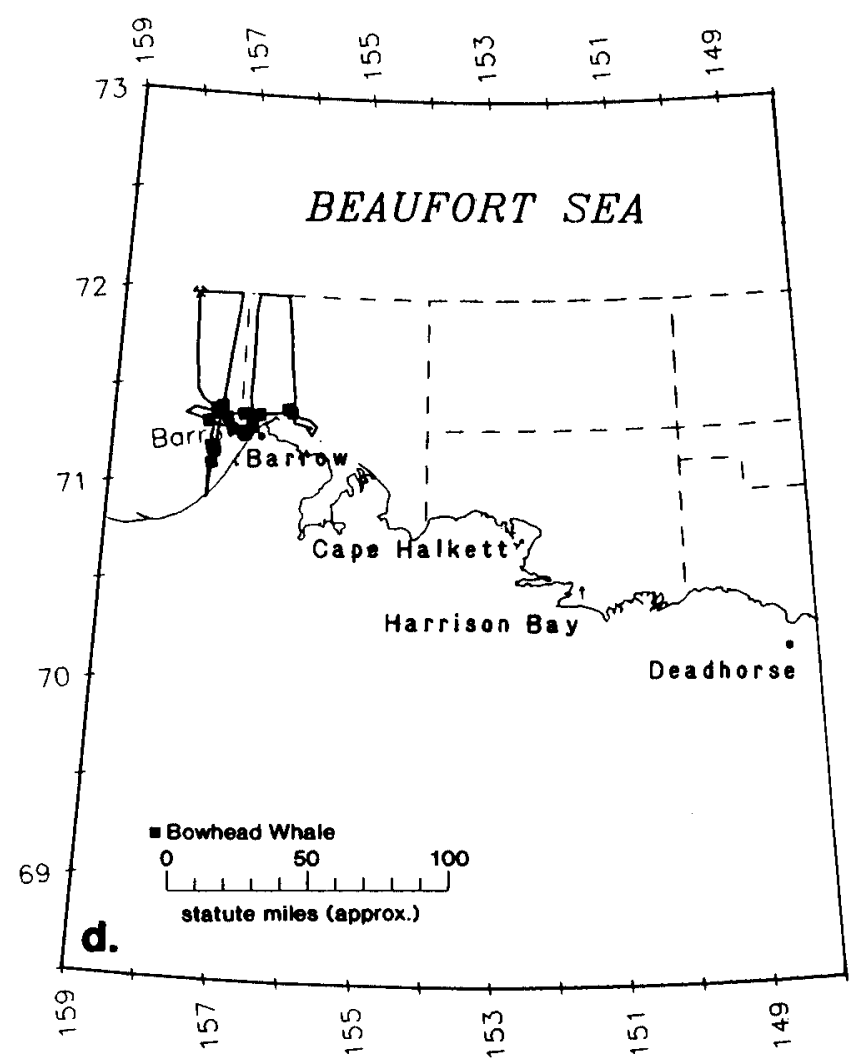

FIG. 1d. Survey track and location of bowhead whale sightings near and east of Point Barrow, Alaska for 21 October 1992. 
On 17 October, while flying in the vicinity of the 15 October sightings, we encountered a large aggregation of feeding bowheads within $35 \mathrm{~km}$ northeast of Barrow, Alaska (Fig. 1b). Nineteen sightings, for a total of 56 whales, were made in an area of open water and new ice. Four of the feeding groups contained eight or more whales. Most of the whales were engaged in bottom or near-bottom feeding (cf. Würsig et al., 1989) because muddy water was frequently observed streaming from their mouths as they surfaced. The groups were easily located due to the sediment-clouded brown water associated with the feeding whales. Glaucous gulls (Larus hyperboreus) were rafting and picking on the sea surface among the feeding whales, presumably feeding on prey brought to the surface. We were unable to sustain our observations that day due to low ceilings.

We returned to the position of the bowhead aggregation on 19 October to further document and delineate the extent of the feeding activity (Fig. 1c). This time we observed 16 groups and 11 singletons, for a total of 104 whales, distributed over a $277 \mathrm{~km}^{2}$ area between $156^{\circ} 02^{\prime} \mathrm{W}$ and $156^{\circ} 25^{\prime} \mathrm{W}$ longitudes and $71^{\circ} 20 \mathrm{~N}$ and $71^{\circ} 31 \mathrm{~N}$ latitudes (Fig. 2). The largest single group contained at least 30 whales, with five other aggregations composed of 5 to 12 individuals. We saw feeding bouts by single whales and subgroups of two to five whales. At times, the whales dove asynchronously, with no apparent pattern to their activity. But on several occasions, subgroups dove and resurfaced synchronously. Five whales were observed diving and surfacing in echelon formation.

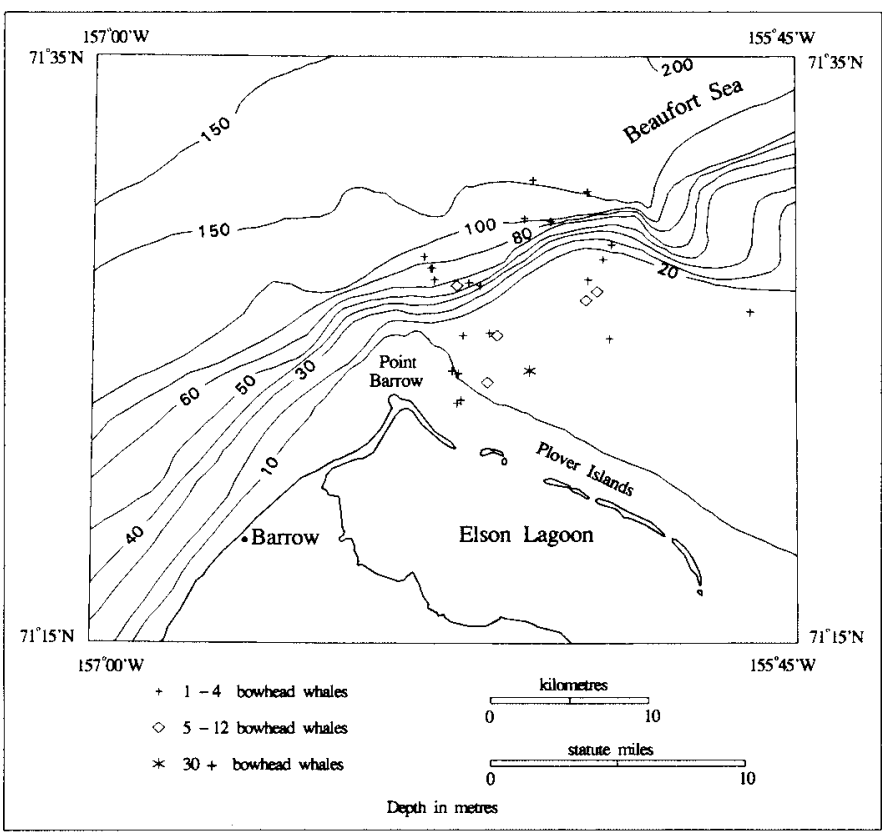

FIG. 2. Detailed view of bowhead whale sightings near Point Barrow on 19 October 1992. The depth contours and coastline of this figure were digitized from Greenberg et al., 1981, and input into a Geographic Information System with whale sightings overlaid.

This subgroup was swimming in a staggered line, with each trailing individual offset a few meters to the right of the preceding individual's fluke. Most feeding activity occurred in water depths $<20 \mathrm{~m}$, although one group was observed feeding in water 50 to $60 \mathrm{~m}$ deep. One group of whales (possibly the latter) exhibited feeding behavior without the associated mud plumes and less mud-clouded water.

There was evidence that the whales were feeding under the dark nilas ice as well as in open water. Numerous whale "tracks" (holes created by whales breaking through the ice to breathe) were present in the ice on the periphery of the feeding activity. Brown sediment clouds and at least three swimming whales were seen beneath the translucent ice.

Not all whales observed in the area were feeding; some were swimming, milling, or resting alone, while others were in small groups of two to three individuals. To the northwest of the feeding activity, at least two bowheads were engaged in breaching and tail-slapping behavior near the ice edge. This behavior was observed once again 3.5 hours later in the same area. We had no way of knowing whether these bowheads were repeat sightings or different whales exhibiting the same behavior only a few kilometers from the previous sightings.

We returned to the position of the bowhead aggregation on 21 October. The area of extensive feeding was almost completely covered with new ice, and we observed only two non-feeding whales. We observed another 28 bowheads loosely distributed west of Point Barrow (Fig. 1d). Most of these whales were traveling westerly $\left(\mathrm{x}=260^{\circ}\right.$ True, $\left.P<0.20\right)$ and most likely represented the last of the feeding group resuming their migration. We did not detect any bowheads during a thorough search of the area on 22 October, the last day of surveys.

We cannot say whether continuous feeding activity occurred in this area prior to our observations. Euphausiids were the dominant prey in the stomachs of whales harvested at Barrow in fall 1992 (C. George, pers. comm. 1992), and some of those whales were taken in the described feeding area as early as 31 August (Harry Brower, Jr., pers. comm. 1992). Thus, whales may have been feeding in this area at least 46 days prior to our observations.

Bowhead whales feed intermittently in the waters east of Point Barrow, possibly due to local oceanographic conditions that increase the availability of bowhead prey in certain years (Moore and Reeves, 1993). To our knowledge, our fall 1992 observations of feeding activity by a large aggregation of bowhead whales were made later in the calendar year than previously reported in the scientific literature and further demonstrate the periodic importance of areas near and east of Point Barrow as a bowhead feeding area in the fall.

\section{ACKNOWLEDGEMENTS}

The quality of this note was improved by the thorough edit of C. Ryan and the reviews of C. Cowles and J. Hubbard, Minerals Management Service; M. Brad Hanson, National Marine Fisheries Service; W. John Richardson, LGL Ecological Research Associates, Inc.; Geoff Carroll, Alaska Department of Fish and Game; and one anonymous reviewer. We thank all of you for your comments. 


\section{REFERENCES}

BRAHAM, H.W., KROGMAN, B.D., and CARROLL, G.M. 1984. Bowhead and white whale migration, distribution, and abundance in the Bering, Chukchi, and Beaufort Seas, 1975-78. National Oceanic and Atmospheric Administration Technical Report NMFS SSRF-778. Rockville, Maryland: U.S. Department of Commerce, N.O.A.A. 39 p.

GREENBERG, J., HART, P.E., and GRANTZ, A. 1981. Bathymetric map of the continental shelf, slope and rise of the Beaufort Sea north of Alaska. Map I-1182-A. Explanatory pamphlet accompanies map. Fairbanks, Alaska: U.S. Department of the Interior, U.S. Geological Survey.

GRIFFITHS, W.B., and BUCHANAN, R.A. 1982. Characteristics of bowhead feeding areas. In: Richardson, W.J., ed. Behavior, disturbance responses and feeding of bowhead whales Balaena mysticetus in the Beaufort Sea, 1980-81. Final Report prepared for the U.S. Department of the Interior, Bureau of Land Management, Washington, D.C., by LGL Ecological Research Associates, NTIS No. PB 86 205879/AS. 347-455.

LJUNGBLAD, D.K., MOORE, S.E., and CLARKE, J.T. 1986. Assessment of bowhead whale (Balaena mysticetus) feeding patterns in the Alaskan Beaufort and northern Chukchi seas via aerial surveys, fall 1979-84. Report of the International Whaling Commission 36:265-272.

LOWRY, L. F. 1993. Foods and feeding ecology, Chapter 6. In: Burns, J.J., and Montague, J., eds. The bowhead whale, Balaena mysticetus. Lawrence, KS: Society for Marine Mammalogy (Special Publication 2). 201-238.

LOWRY, L.F., and FROST, K.J. 1984. Foods and feeding of bowhead whales in western and northern Alaska. Scientific Reports of the Whales Research Institute 35:1-16.

MOORE, S.E., AND CLARKE, J.T. 1992. Patterns of bowhead whale distribution and abundance near Barrow, Alaska, in fall 1982-1989. Marine Mammal Science 8(1):27-36.
1993. Bowhead whale autumn distribution and relative abundance in relation to oil and gas lease areas in the northeastern Chukchi Sea. Polar Record 29(170):209-214.

MOORE, S.E., and REEVES, R.R. 1993. Distribution and movement, Chapter 9. In: Burns, J.J., and Montague, J., eds. The bowhead whale, Balaena mysticetus. Lawrence, KS: Society for Marine Mammalogy (Special Publication 2). 313-386.

RAY, G.C., WARTZOK, D., and TAYLOR, G. 1984. Productivity and behavior of bowheads, Balaena mysticetus, and white whales, Delphinapterus leucas, as determined from remote sensing. In: Perrin, W.F., Brownell, R.L., and DeMaster, D.P., eds. Reproduction in whales, dolphins and porpoises. Reports of the International Whaling Commission, Special Issue 6. Cambridge.

RICHARDSON, W.J., ed. 1987. Importance of the eastern Alaskan Beaufort Sea to feeding bowhead whales, 1985-86. OCS Study MMS 87-0037. Final Report prepared for the U.S. Department of the Interior, Minerals Management Service, Alaska Outer Continental Shelf Region, by LGL Ecological Research Associates, NTIS No. PB 88 150271/AS. 547 p.

TREACY, S.D. 1988. Aerial surveys of endangered whales in the Beaufort Sea, Fall 1987. OCS Study MMS 88-0030. Anchorage, Alaska: U.S. Department of the Interior, Minerals Management Service, Alaska Outer Continental Shelf Region. 141 p. . 1993. Aerial surveys of endangered whales in the Beaufort Sea, fall 1992. OCS Study MMS 93-0023. Anchorage, Alaska: U.S. Department of the Interior, Minerals Management Service, Alaska Outer Continental Shelf Region. 135 p.

WÜRSIG, B., DORSEY, E.M., FRAKER, M.A., PAYNE, R.S., and RICHARDSON, W.J. 1985. Behavior of bowhead whales, Balaena mysticetus, summering in the Beaufort Sea: A description. Fishery Bulletin 83:357-377.

WÜRSIG, B., DORSEY, E.M., RICHARDSON, W.J., and WELLS, R.S. 1989. Feeding, aerial and play behavior of bowhead whales, Balaena mysticetus, summering in the Beaufort Sea. Aquatic Mammals 15(1):27-37. 